NBER WORKING PAPER SERIES

\title{
EURO MEMBERSHIP AS A U.K. MONETARY POLICY OPTION: RESULTS FROM A STRUCTURAL MODEL
}

\author{
Riccardo DiCecio \\ Edward Nelson \\ Working Paper 14894 \\ http://www.nber.org/papers/w14894
NATIONAL BUREAU OF ECONOMIC RESEARCH
1050 Massachusetts Avenue
Cambridge, MA 02138
April 2009

Presented at the NBER conference "Europe and the Euro," Bocconi University, Milan, October 16-17, 2008. We thank the conference organizers, Francesco Giavazzi and Alberto Alesina, and Carlo Favero, Richard Portes, Ulf Soderström, and other conference participants, as well as an anonymous referee, for comments on earlier drafts. We are indebted to Christopher Erceg, Christopher Gust, and David López-Salido for providing code. Charles Gascon, Luke Shimek, and Faith Weller provided research assistance. The views expressed in this paper are those of the authors and should not be interpreted as those of the Federal Reserve Bank of St. Louis, the Federal Reserve System, the Board of Governors, or the National Bureau of Economic Research.

NBER working papers are circulated for discussion and comment purposes. They have not been peerreviewed or been subject to the review by the NBER Board of Directors that accompanies official NBER publications.

(C) 2009 by Riccardo DiCecio and Edward Nelson. All rights reserved. Short sections of text, not to exceed two paragraphs, may be quoted without explicit permission provided that full credit, including (C) notice, is given to the source. 
Euro Membership as a U.K. Monetary Policy Option: Results from a Structural Model

Riccardo DiCecio and Edward Nelson

NBER Working Paper No. 14894

April 2009

JEL No. E32,E42,E52

\begin{abstract}
$\underline{\text { ABSTRACT }}$
Developments in open-economy modeling, and the accumulation of experience with the monetary policy regimes prevailing in the United Kingdom and the euro area, have increased our ability to evaluate the effects that joining monetary union would have on the U.K. economy. This paper considers the debate on the United Kingdom's monetary policy options using a structural open-economy model. We use the Erceg, Gust, and López-Salido (EGL) (2007) model to explore both the existing U.K. regime (CPI inflation targeting combined with a floating exchange rate), and adoption of the euro, as monetary policy options for the United Kingdom. Experiments with a baseline estimated version of the model suggest that there is improved stability for the U.K. economy with monetary union. Once large differences in the degree of nominal rigidity across economies are considered, the balance tilts toward the existing U.K. monetary policy regime. The improvement in U.K. economic stability under monetary union also diminishes if imports from the euro area are modeled as primarily intermediates instead of finished goods; or if we assume that the pressures reflected in foreign exchange market shocks, instead of vanishing with monetary union, are now manifested as an additional source of disturbances to domestic aggregate spending.
\end{abstract}

Riccardo DiCecio

Federal Reserve Bank of St. Louis

Research Division

P.O. Box 442

St. Louis, MO 63166-0442

Riccardo.DiCecio@stls.frb.org

Edward Nelson

Research Division

Federal Reserve Bank of St. Louis

P.O. Box 442

St. Louis, MO 63166

edward.nelson@stls.frb.org 


\section{Introduction}

In June 1999, a poll taken of London-based economists indicated that $65 \%$ believed that the United Kingdom would join the euro area by 2005 . $^{1}$ A decade later, not only has U.K. participation in monetary union not taken place, but such a development no longer seems to be the question of "when, not if" that it once appeared. While euro entry has faded as a likely prospect for the United Kingdom, the decade of coexisting European Central Bank and Bank of England monetary regimes has provided a firmer picture of the differences between the two regimes and of the likely effect that monetary union would have on U.K. economic performance. The analysis that follows uses a structural openeconomy model to evaluate the effect that becoming a euro area member would have on the U.K. economy.

Our discussion in Section 2 provides a background to the debate on European monetary union in the United Kingdom. Section 3 discusses some of the economic arguments that have been raised on both sides of the euro-adoption debate. Section 4 describes the main properties of the model, which is given in detail in an appendix. Section 5 provides simulation results for alternative policies. Section 6 concludes.

\section{The United Kingdom and European economic and monetary union}

The issue of economic and monetary union has been a longstanding - though until the late 1980s only a sporadic — part of the debate about the implications of the United Kingdom's integration into the European Union. The successful negotiations for U.K. entry into the European Economic Community (EEC, now the European Union) during 1970-72 coincided with the EEC's consideration of the Werner Report ${ }^{2}$ proposals for economic and monetary union. In fact, the first instance of the term "euro" being used to describe the putative union currency appears to have been in a discussion in the U.K. press during that period. ${ }^{3}$ The United Kingdom seemingly affirmed its commitment to economic and monetary union in joint statements with EEC members in 1972, 1974, 1985, and 1989. But since 1974, U.K. policymakers have expressed reservations about

\footnotetext{
${ }^{1}$ See MacRae (1999).

${ }^{2}$ Commission of the European Communities (1970).

${ }^{3}$ The Oxford English Dictionary online (www.oed.com) gives a 1971 U.K. press discussion as the first use of the term "Euro." But we have been unable to verify this, as the citation details given in the OED appear to be faulty.
} 
economic and monetary union, which were finally made official with the securing of an "opt-out" clause in 1991 that was executed in 1997.

The United Kingdom did not join the European Communities until January 1, 1973. At a Paris summit in 1972, however, Prime Minister Edward Heath had endorsed the concept of economic and monetary union, with a 1980 deadline. In October 1972, Alec DouglasHome, the Foreign Secretary in the Heath Government, listed European monetary union as a priority in the U.K. government's agenda for the EEC (Associated Press, 1972). But after a change of government and a further Paris summit in 1974, the official position on monetary union changed. Prime Minister Harold Wilson said he "did not find anyone in Paris... who believed there was the remotest possibility of economic and monetary union by 1980," adding that there was "not a hope in hell... of EMU taking place in the near future." Elsewhere in his statement, Wilson appeared to suggest that EMU was undesirable in principle even without the 1980 timetable, but he acknowledged that the 1974 summit communiqué had "made EMU a long-term objective." The wording of the communiqué specifically referred to EMU as an "ultimate goal," though Wilson explained to his Cabinet colleagues that, despite signing the communiqué, "I made it clear it was a goal we do not share." $"$ This discrepancy foreshadowed the pattern in the 1980s, where the United Kingdom would co-sign affirmations of the EMU goal, only to express qualifications in an unwritten or unofficial form.

For the rest of the 1970s, EMU receded as an issue. The EEC's Study Group on the Role of Public Finance (1977, p. 11) noted, "Monetary union, on which much has been written, is... a long way off and will probably have to await major developments in the political, monetary, and fiscal fields." A step in this direction was the European Monetary System (EMS), in particular its exchange rate mechanism (ERM), ${ }^{6}$ which the United Kingdom contemplated joining as a founding member in 1978-79. At the time, however, the exchange rate mechanism was not perceived as part of a formal plan for monetary union. For example, a 1978 U.K. parliamentary committee noted that the EMS proposal was "far from being a major step on the way to European Economic and Monetary Union," and that the Werner proposals for monetary union had been "agreed... but subsequently abandoned." (Expenditure Committee, 1978, p. X.)

\footnotetext{
${ }^{4}$ Wilson, in House of Commons Debates, December 16, 1974, pages 1127 and 1139.

${ }^{5}$ Wilson speaking on December 12, 1974, quoted in Castle (1980, p. 249).

${ }^{6}$ The "ERM" terminology only became prevalent in U.K. policy debates starting in mid-1989; in most of the pre-1989 discussions within the United Kingdom, the term EMS was used to refer to the exchange rate mechanism.
} 
The lull in progress toward European economic and monetary union was broken in 1985 with agreement on a single market. This involved the United Kingdom and other EEC members signing a treaty amendment referring to economic and monetary union as a goal. The United Kingdom under Prime Minister Margaret Thatcher further joined in Madrid (1989) and Dublin (1990) summit declarations endorsing a process that would culminate in economic and monetary union. In explaining her apparent endorsement of EMU on occasions like these, Thatcher said in 1990 that her definition of EMU was "economic and monetary cooperation.",

In 1990 Thatcher came out unambiguously against monetary union, declaring the United Kingdom's own currency (the pound sterling) its "greatest expression of sovereignty." Disagreement over EMU played a key role in her forced resignation. Thatcher's successor, John Major, was not opposed unconditionally to EMU but took the key step of securing for the United Kingdom the option not to participate in monetary union. At the Maastricht summit in December 1991, Major obtained an opt-out provision as a condition of U.K. participation in the Maastricht Treaty. The opt-out pertained to "Stage 3" of economic and monetary union, i.e., the stage at which the union amounted to a single currency.

The likelihood of the United Kingdom joining in monetary union receded further with the collapse of its membership of the exchange rate mechanism in 1992 and the perceived success of domestic monetary policy in the early years of inflation targeting (1992-97). For the 1997 general election, both major political parties were committed to a policy of seeking referendum approval before any final decision to enter monetary union could be formalized. Shortly after its election in 1997, the Blair Government "committed the U.K. to the principle of joining the single currency" (HM Treasury, 2003a, p. 1), but made any recommendation of actual entry (and hence a referendum) conditional on the five economic tests being passed. The five economic tests (with our numbering in square brackets) are: ${ }^{9}$

[1] Are business cycles and economic structures compatible so that we and others could live with euro interest rates on a permanent basis?

\footnotetext{
${ }^{7}$ Thatcher, interview with Sunday Times, October 15, 1990, stored at www.margaretthatcher.org.

${ }^{8}$ Thatcher, in House of Commons Debates, October 30, 1990, page 874.

${ }^{9}$ Given in HM Treasury (2003a, p. I), but originally stated (with some variation in wording) by the Government in 1997.
} 
[2] If problems emerge[,] is there sufficient flexibility to deal with them?

[3] Would joining EMU create better conditions for firms making long-term decisions to invest in Britain?

[4]What impact would entry into EMU have on the financial services industry? [5] In summary, will joining EMU promote higher growth, stability and a lasting increase in jobs?

The U.K. Government determined in 1997 and 2003 that these tests had not been satisfied, and so did not proceed to a referendum on U.K. membership of the euro area. (See especially HM Treasury, 2003b.)

The prospect of the United Kingdom becoming a member of the euro area now seems remote. Good macroeconomic performance from 1997 to 2007, the related consolidation of the inflation targeting regime, and the move to even greater seniority within the U.K. government of critics of membership (most notably Gordon Brown's move from Chancellor of the Exchequer to Prime Minister) have all been factors reducing the likelihood of euro adoption.

Let us consider, however, the five economic tests and the extent to which our analysis below can bear on them. Question [4] is an industry-level question not easy to answer with a macroeconomic model, while [3] and aspects of [5] cover questions more suitably answered with a model that accounts for changes in long-term economic growth. We therefore consider those questions most suited to a macroeconomic analysis: the interrelated questions [1] and [2] as well as the "stability" aspect of test [5]. These were also the aspects of the five economic tests which the U.K. authorities (in HM Treasury, 2003a) stressed that the United Kingdom had not met. We interpret these tests as jointly amounting to a test of whether monetary union improves upon or is at least competitive with the existing U.K. monetary policy regime (inflation targeting) in contributing to macroeconomic stabilization.

Before outlining our modeling strategy for investigating this question, we consider some key aspects of the economic debate on the United Kingdom's place in European monetary union. 


\section{The economic debate over the merits of monetary union}

Some early discussions of the United Kingdom's position in the European Union took monetary union as an eventual implication of movement to a single trading market. For example, Lionel Robbins stated in 1971, "I do not think that in the end a common market, just like that, can function well if there is not something like a common money." ${ }^{10}$ In 1991, former Prime Minister Edward Heath said that "any economist" would say that that once the European Union became a single market (in 1992), "there was no alternative to a single currency." "11 These positions, have, however, not had an enduring influence, and the merits of monetary union for the United Kingdom are now seen as an issue separable from the merits of membership in the European Union.

As noted above, a major element of the opposition to European monetary union has taken the form of opposition to the perceived loss of political sovereignty, and some adherents to that political argument regard it as a sufficient condition for rejecting monetary union even if euro membership could be shown to be desirable on economic grounds. This seemed to be the stand taken by several members of the Conservative governments over the 1990s—see Stephens (1997, pp. 309-315) — but that position was decisively renounced as government policy when in 1997 the Blair Government appealed exclusively to economic merits as the criteria for entry.

The most important implication of monetary union for economic management was identified by Prime Minister Wilson's observation in 1974 that union "would mean one central bank, one central currency... [E]very country would have to pursue exactly the same policy with that single currency..." Wilson argued that therefore it was an "illusion" to believe that monetary union would occur. ${ }^{12}$ While Wilson's conclusion proved to be a flawed prediction for much of the European Union, his discussion of the main economic implications of monetary union did anticipate much of the subsequent debate. This debate takes as a starting point the acceptance that a single macroeconomic or demand management (specifically, monetary) policy is implied by union, and aims to establish whether the associated loss of flexibility for the U.K. economy is outweighed by economic benefits of membership. The debate on euro membership therefore combines two long-lasting themes in U.K. policy debates: the desirable degree of economic

\footnotetext{
${ }^{10}$ Robbins, in House of Lords Debates, July 28, 1971, page 450.

${ }^{11}$ Heath, in House of Commons Debates, November 21, 1991, page 459.

${ }^{12}$ Wilson, in House of Commons Debates, December 16, 1974, pages 1127-1128.
} 
integration with "Europe"; and whether the United Kingdom should give up its freedom to have its own monetary policy. ${ }^{13}$

Many of the details of the economic debate on U.K. membership have been concerned with exchange rate behavior. Euro adoption would mean the end of a regime in which the U.K. pound sterling floats against the euro. Much of the discussion of Buiter (1999), Minford (2002), and Artis and Ehrmann (2006) centers on the issue of whether the exchange rate, when allowed to float, adapts efficiently to shocks; or if it instead fails to respond to fundamentals in a stabilizing manner, and so (ceteris paribus) magnifies macroeconomic variability. Such a way of framing the issue happens to understate the benefits for a country of monetary policy autonomy. For it is certainly not the case that the benefits of monetary autonomy are absent if the exchange rate is driven by nonfundamental factors. Irrespective of what factors drive the exchange rate, a floating rate confers on the central bank autonomy in determination of the amount of base money in existence and so the ability to use domestic short-term interest rates as a policy instrument. This benefit does not depend on a well-behaved exchange rate - it is completely ensured by Phillips and IS curves that have standard properties (i.e., with aggregate demand sensitive to real short-term interest rates — possibly indirectly via a term-structure connection to long rates; and with prices adjusting gradually to aggregate demand, so that a Phillips curve that becomes vertical in the long run describes inflation dynamics). So for the exchange rate to respond to "fundamentals" is not a necessary condition for a floating exchange rate to be desirable. In relation to this point, Corsetti, Dedola, and Leduc (2007) present a model where the exchange rate fails completely to adhere to fundamentals, yet the monetary policy strategy followed by the U.K. authorities in preference to monetary union-i.e., focusing on a CPI inflation target alongside a floating exchange rate-is optimal.

Nevertheless, it is true that one possible benefit of a floating rate is its potential ability to contribute to stabilization. The debate on whether the exchange rate provides this stabilizing role in practice can be represented by reference to a standard uncovered interest parity condition (see e.g., Woodford, 2001, p. 308):

\footnotetext{
${ }^{13}$ Debates on the second issue predate the creation of any version of the European Union. Indeed, one of the pioneer Keynesians, Richard Kahn, argued, "If Keynes can be said to have devoted his life to anything, it is to liberating internal policy from the domination of external factors." (Kahn, 1956, p. 113.) Milton Friedman made a similar assessment of Keynes' contribution (Friedman, 1983).
} 
$q_{t}=\mathrm{E}_{t} q_{t+1}-\left[\left(R_{t}-\mathrm{E}_{t} \pi_{t+1}\right)-\left(R_{t}^{*}-\mathrm{E}_{t} \pi_{t+1} *\right)\right]+\psi_{t}$

where asterisks denote other-economy values, $q_{t}$ is the log real exchange rate, $R_{t}$ is the domestic short-term nominal interest rate in quarterly units, $\pi_{t}$ is quarterly inflation, and $\psi_{t}$ is an exogenous time-varying risk-premium (i.e., a shock to the UIP condition). There is wide agreement that, in practice, the real exchange rate and the nominal exchange rate move in the same direction in the short run under floating exchange rate regimes. Therefore, claims about whether the nominal exchange rate performs a stabilizing function can be mapped into similar claims about the short-run behavior of $q_{t}$.

The view that a floating exchange rate helps macroeconomic stabilization can be broken into two elements: (i) Different shock patterns or different structure in the home economy, relative to the other economy, might lead to the "natural interest rate" differing across economies. To the extent that stabilization of the home economy's output gap and its aggregate inflation rate require adjustment of nominal interest rates to levels different from those prevailing in the other economy, this adjustment can be accomplished because exchange rate flexibility allows interest rates to differ across economies-i.e., $q_{t}$ and $\mathrm{E}_{t} q_{t+1}$ are free to move to satisfy the UIP condition if monetary policy moves domestic real and nominal interest rates away from the corresponding other-economy values. (ii) Fluctuations in the risk premium $\psi_{t}$ may occur for reasons of economic fundamentals, and the efficient response might be a nominal exchange rate reaction rather than a reaction of domestic interest rates. With a floating nominal exchange rate, this can occur, and this kind of adjustment has, for example, often been argued to describe the Australian dollar's reaction to the 1990s Asian market crises. Monetary union, however, precludes an adjustment along these lines of the domestic economy and of the nominal exchange rate.

The advocacy of euro membership for the United Kingdom in Buiter (1999) does not use an explicit model, but Buiter's analysis implicitly assumes away the model elements that deliver the scenarios described in (i) and (ii) above. Buiter (1999, p. 30) essentially rules out case (i) in his statement that "in a rather small and open economy like the U.K., monetary policy works primarily (even if not reliably) through the exchange rate." The position that the exchange-rate channel is the main channel through which monetary policy operates in an open economy is very restrictive. It is true that the MundellFleming model and some modern optimization-based models remove the real interest rate 
from the list of variables that the home-country central bank can influence in the short run. ${ }^{14}$ But this result does not hold in models in which the aggregate consumer price index is sticky (e.g., models where imports are intermediates alone and final goods prices are sticky, as in McCallum and Nelson, 1999; or models where imports are final goods but are priced sluggishly, as in Monacelli, 2005). And it is not obvious that the domestic channel of monetary policy is negligible in open economy models in general. In other words, a portion of aggregate real spending may be sensitive to the real interest rate rather than just the real exchange rate, so this component of aggregate demand can be affected by any monetary policy that can influence real interest rates even if monetary policy's impact on the exchange rate is unreliable. Work done with explicitly optimization-based open-economy models with nominal rigidities does not in general support the notion that, in an open economy, monetary policy ceases to work through any channel other than the exchange rate. Thus Faia and Monacelli (2008, p. 745), while concluding that "the nature of optimal monetary policy in an open economy emerges as fundamentally different from the one of a closed economy," do not deny a domestic monetary policy channel; domestic real short-term interest rates appear in their consumption Euler equation in the usual manner, so monetary policy can influence aggregate demand via this "domestic" channel if it is able to affect domestic short-term real interest rates in the short run.

The existence of a substantial domestic-spending channel of monetary policy seems to be widely accepted for the analysis of the United Kingdom, and the Bank of England's official descriptions of its view of monetary policy transmission include a prominent domestic channel (see, for example, Bank of England, 1999). Moreover, the U.K. Treasury's assessment of the costs and benefits of euro adoption emphasized the different arrangements for mortgage lending across the United Kingdom and euro area, a comparison that would be irrelevant if no domestic channel of monetary policy existed. ${ }^{15}$ The record of U.K. monetary policy episodes also suggests that aggregate demand and inflation do respond to monetary policy actions even when the behavior of the exchange rate does not appear to be in keeping with the direction expected from a monetary policy change: for example, tightenings in 1976 and 1989 were followed by contractions in aggregate demand, even though the sterling exchange rate depreciated for protracted

\footnotetext{
${ }^{14}$ See Woodford (2007) for a discussion of the capacity of the central bank to influence real rates in optimizing open-economy models.

${ }^{15}$ See H.M. Treasury (2003b). The Treasury emphasized the fact that in the U.K. mortgage interest rates are predominantly adjustable, while in the euro area they are often fixed. See Rubio (2008) for an investigation of this distinction in a general equilibrium model.
} 
periods. The predominant conclusion from theory and evidence is that domestic channels of monetary policy are present and substantial, so, as suggested above, floating exchange rates confer on the central bank the ability to determine nominal aggregate demand and the inflation rate, even if the exchange rate channel cannot be relied upon.

In opposition to position (ii), the euro entry advocates have argue that the UIP shock $\psi_{t}$ is not a fundamental shock; rather, it reflects an inefficiency or "noise" created by the foreign exchange market, and so any movement it tends to induce in $q_{t}$ is undesirable. By analogy with the cost-push shock in large DSGE models (see especially Smets and Wouters, 2005, p. 163), the UIP shock is, according to this argument, a friction that distorts prices and moves the economy further away from its efficient allocation, and is not a shock to which real variables would respond in an efficient flexible-price equilibrium. This argument leads to Buiter's (1999) position that it is desirable to abolish the sterling/euro foreign exchange market by imposing monetary union. Then the condition $R_{t}=R_{t}^{*}$ is an identifying feature of a monetary union. The nominal exchange rate is removed from the system as a variable. To the extent that UIP shocks owe their existence to the market for nominal foreign exchange, the elimination of that market removes UIP shocks from the model. Monetary union is, in that case, materially different from both floating-exchange-rate and fixed-exchange-rate environments.

The view of critics of monetary union is that union does not remove UIP shocks; instead, it changes the way that they create pressures. Blanchard (1997, p. 288), for example, argues that "while a common currency will indeed eliminate exchange rate crises, it will not eliminate the underlying reason for such crises - namely, the fact that different interest rates, as well as adjustments in exchange rates, are needed..." Elimination of a floating nominal exchange rate, according to this view, removes a convenient means with which to adapt to the pressure of UIP shocks. Absent floating exchange rates, the pressure of such shocks might be felt in other economic relationships. For example, the pressure formerly felt as UIP shocks might now manifest itself as an increase in the variance of shocks to the IS equation.

All in all, the a priori arguments that led to Buiter's (1999) conclusion that the case for euro adoption by the United Kingdom was "overwhelming" do not seem compelling, as modern open-economy models produce many counterexamples. It is desirable instead to consider an explicit structural model that embeds and quantifies many of the model elements underlying the debate on monetary union. We do this in Section 4. 


\subsection{The sterling appreciation}

The United Kingdom experienced a "strong pound" period starting in 1996 and continuing during nearly a decade of the euro's existence (see Figure 1). This period has been said to demonstrate the defects of floating exchange rates as an arrangement for the United Kingdom. It has been emphasized by critics of floating that the sterling appreciation is difficult to trace to economic fundamentals (see e.g., Cobham, 2006). The recent sudden reversal of the pound appreciation, at a time of worldwide contraction in the financial services business, is said by euro-membership advocates to demonstrate further the disadvantage of the United Kingdom's exercise of its opt-out from euro participation. Proponents of U.K. participation contend that the strong pound shifted U.K. employment from the exchange-rate-sensitive manufacturing sector to the financial services sector, and that the latter increase in employment has proved to be ephemeral.

In our view, however, this episode does not provide unambiguous evidence against the advantages claimed for floating exchange rates. In particular, the case made by membership proponents neglects the major contribution to macroeconomic stabilization that U.K. monetary policy made during the strong-pound period of 1996-2007. Monetary Policy Committee decisions had a favorable effect during the period of stagnant or falling manufacturing output and industrial production indices from 1997 to 2007. In 1990-92, the United Kingdom had a fixed exchange rate and no monetary policy autonomy; during this earlier episode of an overvalued pound, contraction proceeded in both the manufacturing sector and aggregate economic activity. In 1997-2007, by contrast, the strong pound was associated with stagnant or declining indices of industrial and manufacturing production, but also with continuous and respectable growth in real GDP. This is brought out in Figure 2, which plots annualaverage data (from IFS) of U.K. industrial production and U.K. real GDP for 1990-2007. We would argue that, by concentrating on the stabilization of macroeconomic aggregates, the Monetary Policy Committee over this period managed to stop the manufacturing contraction from being associated with aggregate economic contraction. The reason it was able to do this was the United Kingdom's monetary policy autonomy, which neither a monetary union nor fixed exchange rate would have permitted.

As for the rapid end of the strong-pound era in 2008, this can be seen as a stabilizing development. By stimulating net exports, the turnabout in sterling behavior lessened the implications for U.K. aggregate output and employment of the downturn in the U.K. 
Figure 1. U.K./euro area exchange rate, 1990-2008 (pound sterling received per euro)

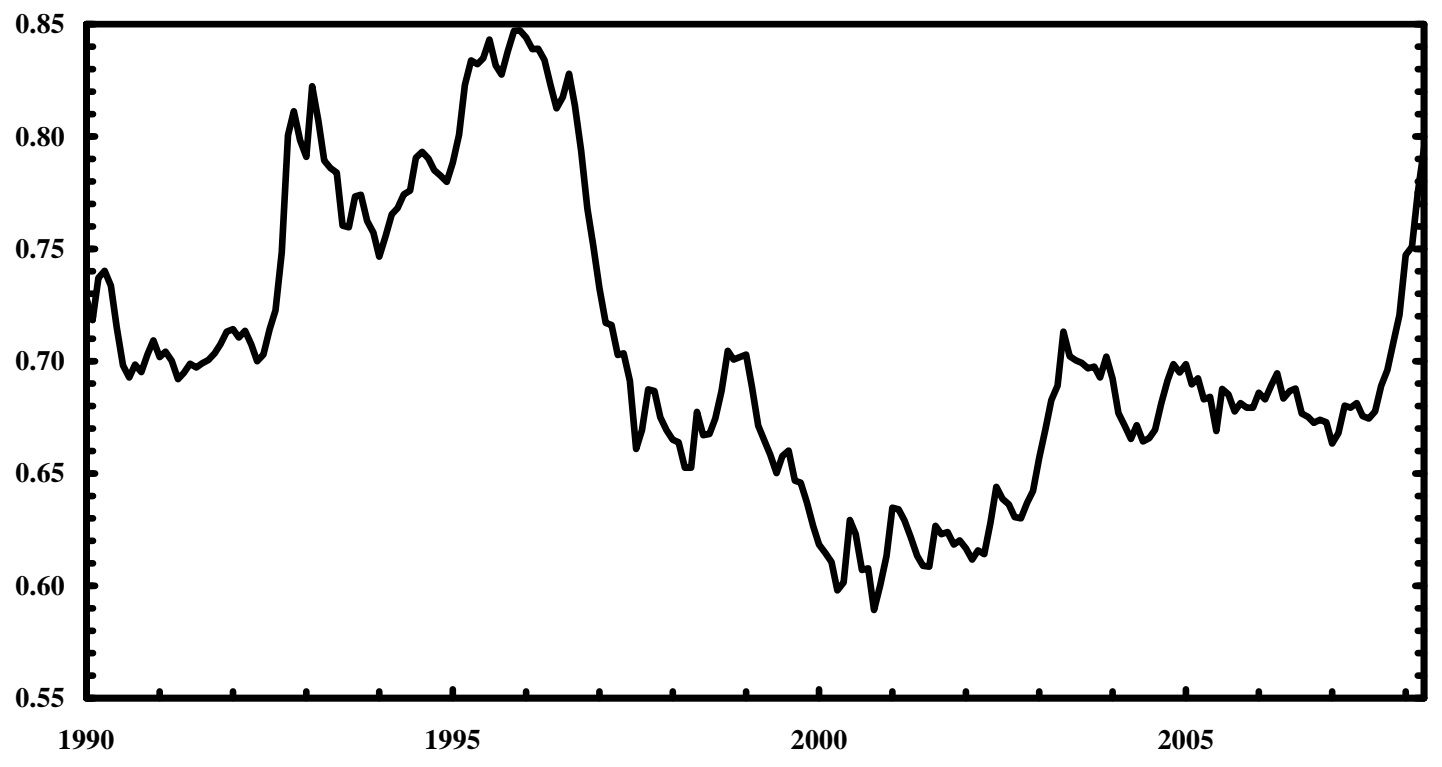

Source: Haver/OECD

Figure 2. Indexes of Industrial Production and Real GDP, United Kingdom, 1997-2007 (index $2000=100$ )

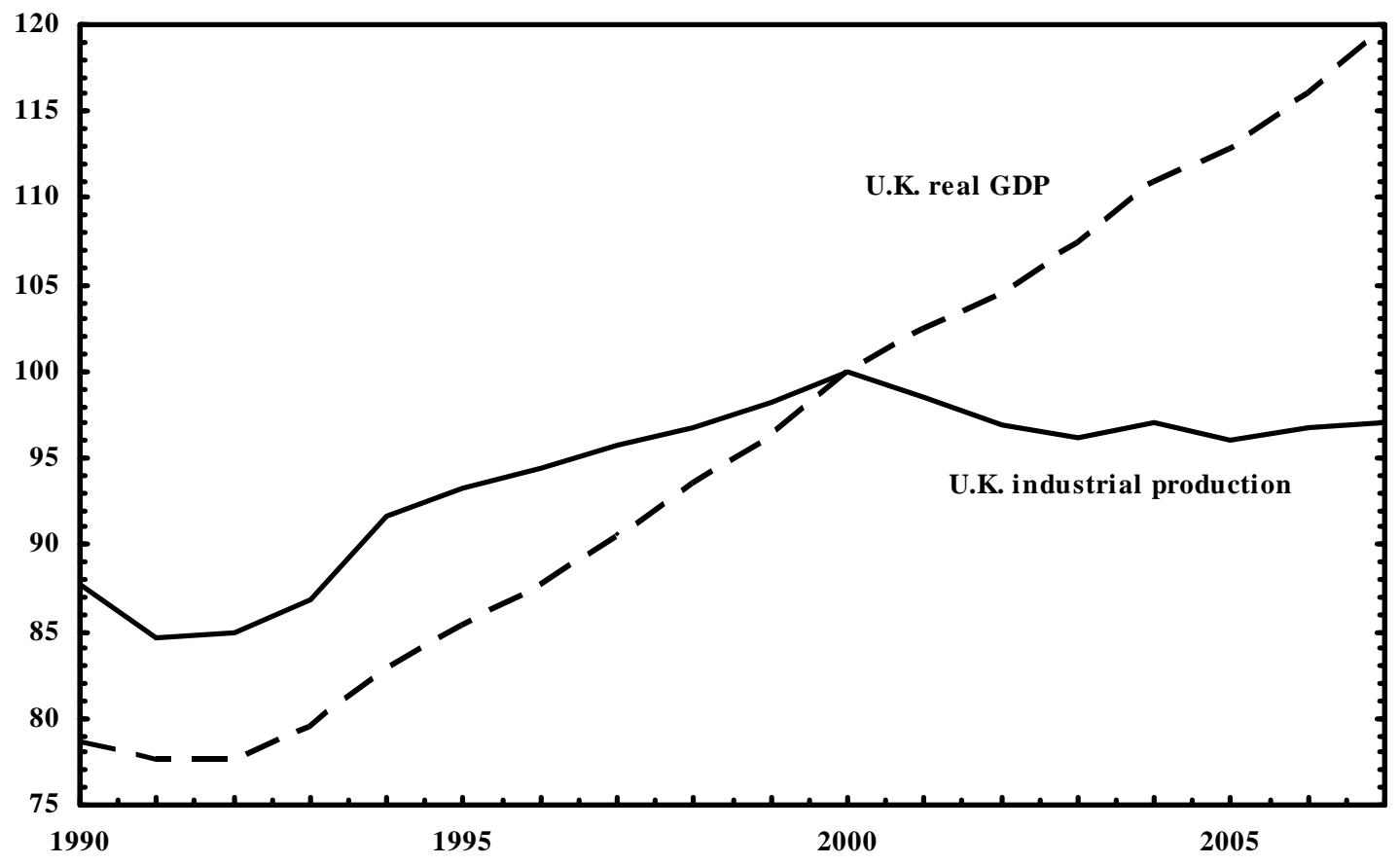

Source: Haver/IFS 
financial services business. The floating pound has also allowed the MPC to ease monetary policy vigorously relative to euro area policy — a room to move dramatically exemplified by the MPC's 150-basis point cut in the U.K. Bank Rate in November 2008, and by its adoption of quantitative easing in 2009 .

\section{A structural model for considering monetary union questions}

The model we use is the two-country open-economy system of Erceg, Gust, and LópezSalido (EGL) (2007). This model has several major attractions for the study of the United Kingdom's monetary policy options. First, the model is based on optimizing behavior, so consideration of alternative monetary regimes (in either the U.K. economy or the euro area) is a natural and legitimate experiment. In particular, we can explore CPI inflation targeting and monetary union as U.K. monetary policy options. Second, the model is flexible enough to allow the two economies to be asymmetric on several important dimensions: e.g., relative size, technology, shock specification and degree of nominal rigidity (for both prices and wages). This flexibility allows us to determine the impact of monetary union in the presence of different economic structures (and different shock processes) in the United Kingdom and the euro area. Third, Erceg, Gust, and López-Salido (2007) show that the model allows the domestic real interest rate and output gap to be affected substantially by domestic shocks, so there is a nontrivial "domestic" channel despite the presence of openness. This means that our results do not depend on the caricature that U.K. monetary policy effectiveness relies on an exchange rate channel. Fourth, the model can be adjusted to allow for a portion of the volume of imports to be intermediate goods. We can therefore use a feature that was advocated for optimizing open-economy models by McCallum and Nelson (1999), and found convenient for the analysis of monetary policy in open economies by Erceg (2002) and Smets and Wouters (2002).

As the model has been laid out in detail in Erceg, Gust, and López-Salido (2007), we simply summarize its main elements here, presenting the basic equations in an appendix. Households' consumption choice is represented by a standard Euler equation.

Government spending in each country is exogenous and is the source of an "IS" shock. The production function features labor input, an exogenous technology shock specific to each economy, and a fixed capital stock. Labor is immobile across countries. Firms and workers enter the goods and labor markets respectively with a degree of monopoly power and with Calvo-style obstacles to adjustment of the offered prices for their goods and 
labor services. These contracts are augmented by dynamic indexation: all wage contracts are scaled up by the prior period's wage inflation rate; all price contracts, by prior price inflation. In our estimated version of the model, imports are final consumer goods. The prices of imports are flexible.

\subsection{Specification and estimation}

We assume that the home economy's size is $20 \%$ that of the other economy, in order to give the model a "United Kingdom = home economy; euro area = other economy" interpretation. We set the steady-state share of government spending in GDP to 0.33 in the United Kingdom, 0.338 in the euro area. The import share of GDP for each economy is intended to capture the degree of each economy's trade with one another. We make the share $13.5 \%$ for the United Kingdom; together with the relative sizes of the economy, this implies a $2.7 \%$ import share for the euro area. The latter takes such a low value because we are neglecting non-U.K. imports into the euro area, given the model's twoeconomy structure. We fix the exchange rate elasticity of traded goods at EGL's baseline value of 1.5 and the steady-state wage markup in both economies at $50 \%$. The discount rate $(\beta)$ is set at 0.9925 , the intertemporal elasticity of substitution is set at $1 / \sigma=1 / 2$, and the inverse of the Frisch elasticity of labor supply assumed to be $\chi=5$.

While we estimate the intertemporal elasticity of substitution for consumption and the labor supply elasticity of households using U.K. and euro area data, we constrain the estimate of each parameter to be the same across the two economies.

The monetary policy rule specification is similar but not identical across economies. For the United Kingdom, the monetary policy rule has the short-term nominal interest rate respond in a smoothed manner to the lagged four-quarter retail price inflation rate (which we use as the empirical measure for the United Kingdom of consumer price inflation, $\pi_{C}$ ) and to lagged detrended log output $y$ :

$$
\begin{aligned}
R_{t}^{U . K .} & =\rho_{R} R_{t-1}^{U . K .}+\left(1-\rho_{R}\right) \gamma_{\pi}\left(0.25^{*}\left(\pi_{C, t-1}^{U . K .}+\pi_{C, t-2}^{U . K .}+\pi_{C, t-3}^{U . K .}+\pi_{C, t-4}^{U . K .}\right)\right) \\
& +\left(1-\rho_{R}\right) \gamma_{y} y_{t-1} \text { U.K. }+e_{R t}{ }^{U . K .}
\end{aligned}
$$

Here constants are suppressed, and the monetary policy shock $e_{R t}$ is assumed to be an $\mathrm{AR}(1)$ process. Other than lagging the variables one more period, this specification is a restricted version of the policy rule estimated for the United States by Rotemberg and 
Woodford (1997), and also follows their use of loglinearly detrended real GDP as the variable to which the authorities respond. Again paralleling Rotemberg and Woodford's specification, the above reaction function above delivers a "long-run" rule of the Taylor form. Our modeling of policymaker behavior using this simple three-parameter rule requires justification in light of Favero's (2001, p. 237) position that "a strategy closer to the spirit of intertemporal optimization seems more appropriate" in the estimation of policy rules. The use of a simple rule can be defended both on practical grounds - the EGL model is too large for the implied optimal-policy conditions to deliver rules tractable enough for econometric estimation - and for reasons of realism - the inflation variable that U.K. policymakers over our sample concerned themselves with was a CPIlike concept, not the combination of wage inflation and domestic-goods price inflation that the EGL model would tend to suggest should be targeted.

For the euro area, a similar policy rule specification is estimated, though with no constraint that the estimated responses, or the $\mathrm{AR}(1)$ parameter and innovation variance for the shock, be the same as in the United Kingdom. An important qualification is that for the euro area we assume that the inflation variable that enters the rule is the (annualized) one-period lagged quarterly GDP deflator inflation rate (as opposed to the lagged four-quarter CPI-type rate in the U.K. case). The deflator inflation rate is assumed to enter the rule even though it is the HICP aggregate that we use as an observable in obtaining our estimates below (where it is used to correspond, for the euro area, to the model's consumer price index). The assumption that euro area policy responds to deflator inflation follows Smets and Wouters (2005). ${ }^{16}$

Each economy has Phillips curves for wage and for price adjustment. Each Phillips curve has its own univariate AR(1) shock term. The remaining shocks in the model are two real shocks for each economy_-government spending and technology—and a shock that we add to the EGL model, namely a shock to the UIP condition, so that the UIP condition in our model resembles equation (1). The two real shocks for each economy (four in total) and the UIP shock are assumed to be AR(1) processes. Because asymmetry of shocks is a central issue for the debate on monetary union, the stand we take on correlations of shocks is important. We allow the government spending shock to be

\footnotetext{
${ }^{16}$ The United Kingdom is the "rest of world" for the euro area in the two-economy model we are using. Assuming a euro-area monetary policy response to deflator inflation captures, more than would an assumption of a policy response to consumer prices, the notion that euro area policy does not respond to U.K. inflation when the United Kingdom is outside the monetary union.
} 
correlated across economies, and so too the technology shock to be correlated across economies. This cross-correlation is allowed for by empirical estimation of crosscorrelations of the shock innovations. We constrain the monetary policy and Phillips curve shocks to be uncorrelated across economies.

The data used in model estimation are, for each economy, detrended logs of per capita consumption, output, and the quarterly real wage (with consumer prices used to deflate nominal wages); (consumer/retail) price inflation for each economy; the nominal U.K. Treasury bill rate; the euro area short-term nominal interest rate; and the change in the nominal exchange rate. Logs of output, consumption, and the real wage are detrended over 1980-2005. U.K. data sources are described in DiCecio and Nelson (2007). ${ }^{17}$ Euro area data come from the ECB's Area Wide Model database (see Fagan, Henry, and Mestre, 2001) and other ECB sources. The sterling/euro exchange rate is from Haver/IFS. Population data are from Haver, the ECB, and (for the United Kingdom) the Office of National Statistics.

We estimate the model by Bayesian likelihood methods (see Smets and Wouters 2003, 2007) on the sample period 1981 Q1-2005 Q4, ${ }^{18}$ and report parameter estimates in Tables $1 \mathrm{~A}$ to $1 \mathrm{C}$. The posterior estimates indicate a standard amount of price stickiness (around twice-a-year price adjustment, other than the adjustment occurring via the indexation term) for both economies. But there is little estimated wage stickiness. For the euro area, this result is puzzling in light of estimates such as those of Smets and Wouters (2003). One of the simulation experiments that we undertake below allows for more wage rigidity in the euro area. For both economies, the rule estimates indicate substantial interest-rate smoothing, a long-run response to inflation close to 1.5 , and an output response somewhat below the value $(0.5 / 4=0.125)$ associated with the Taylor rule.

\footnotetext{
${ }^{17}$ In addition to the U.K. variables described there, we have nominal wages for the United Kingdom among our observables. Nominal wages for the United Kingdom consist of total compensation (Office of National Statistics series dtwm.q), divided by aggregate employment (series bcaj.q).

${ }^{18}$ Starting estimation in 1981 allows the overhaul of doctrine that took place in U.K. economic policymaking in the late 1970s, documented in Nelson (2008), to make itself felt in changed monetary policy responses to the state of the economy. As a related matter, omitting pre-1980 observations from the sample helps avoid inclusion in estimation many of the substantial breaks in means, trends, and variances from the 1970s to the 1980s in the U.K. data, documented for example by Stock and Watson (2002), Benati (2008), Boero, Smith, and Wallis (2008), and Surico (2008).
} 
Table 1A. Bayesian estimates of EGL (2007) model on U.K. and euro area data Estimation period 1981 Q1-2005 Q4 Structural and monetary policy rule parameters

\begin{tabular}{|c|c|c|c|c|}
\hline \multirow{2}{*}{ Parameter interpretation } & Prior & \multicolumn{3}{|c|}{ Posterior } \\
\hline & $\begin{array}{c}\text { Mean } \\
\text { (St. Dev.) }\end{array}$ & Mode & Mean & $5 \%, 95 \%$ \\
\hline Price adjustment probability, U.K. & $\begin{array}{c}0.5000 \\
(0.1000)\end{array}$ & 0.5161 & 0.5289 & $\begin{array}{l}0.4461 \\
0.6132\end{array}$ \\
\hline Wage adjustment probability, U.K. & $\begin{array}{c}0.5000 \\
(0.1000)\end{array}$ & 0.1294 & 0.1417 & $\begin{array}{c}0.0977 \\
0.1851\end{array}$ \\
\hline Price adjustment probability, euro area & $\begin{array}{c}0.5000 \\
(0.1000)\end{array}$ & 0.4720 & 0.4954 & $\begin{array}{c}0.4066 \\
0.5923\end{array}$ \\
\hline Wage adjustment probability, euro area & $\begin{array}{c}0.5000 \\
(0.1000)\end{array}$ & 0.1102 & 0.1287 & $\begin{array}{c}0.0800 \\
0.1790\end{array}$ \\
\hline $\begin{array}{l}\text { Labor supply elasticity } \\
\text { (both economies) }\end{array}$ & $\begin{array}{c}2.0000 \\
(0.7500) \\
\end{array}$ & 4.0525 & 4.0833 & $\begin{array}{l}3.2859 \\
4.8279\end{array}$ \\
\hline $\begin{array}{l}\text { Intertemporal elasticity of consumption } \\
\text { (both economies) }\end{array}$ & $\begin{array}{c}1.5000 \\
(0.3750)\end{array}$ & 3.2325 & 3.2495 & $\begin{array}{l}2.8352 \\
3.6897\end{array}$ \\
\hline Interest smoothing, U.K. policy rule & $\begin{array}{c}0.7500 \\
(0.1000) \\
\end{array}$ & 0.4544 & 0.4609 & $\begin{array}{l}0.3444 \\
0.5782 \\
\end{array}$ \\
\hline Inflation response, U.K. policy rule & $\begin{array}{c}1.5000 \\
(0.2500)\end{array}$ & 1.6423 & 1.6874 & $\begin{array}{l}1.5032 \\
1.8676 \\
\end{array}$ \\
\hline Output response, U.K. policy rule & $\begin{array}{c}0.1250 \\
(0.0500) \\
\end{array}$ & 0.1116 & 0.1193 & $\begin{array}{l}0.0792, \\
0.1627\end{array}$ \\
\hline Interest smoothing, euro area policy rule & $\begin{array}{c}0.7500 \\
(0.1000) \\
\end{array}$ & 0.7896 & 0.7926 & $\begin{array}{l}0.7585 \\
0.8296\end{array}$ \\
\hline Inflation response, euro area policy rule & $\begin{array}{c}1.5000 \\
(0.2500) \\
\end{array}$ & 1.2744 & 1.3197 & $\begin{array}{l}1.1741, \\
1.4565\end{array}$ \\
\hline Output response, euro area policy rule & $\begin{array}{c}0.1200 \\
(0.0500) \\
\end{array}$ & 0.0845 & 0.0917 & $\begin{array}{c}0.0460 \\
0.1358\end{array}$ \\
\hline
\end{tabular}

Note: The estimated probabilities of wage and price adjustment are the probability that no discretionary adjustment is allowed this period (in which case a default adjustment takes place of indexation to the previous period's inflation rate of the index in question). Beta distribution prior used for these probabilities; normal distribution prior used for the other parameters. 
Table 1B. Bayesian estimates of EGL (2007) model on U.K. and euro area data Estimation period 1981 Q1-2005 Q4 Shock autoregressive processes

\begin{tabular}{|c|c|c|c|c|}
\hline \multirow[t]{2}{*}{ Parameter interpretation } & Prior & \multicolumn{3}{|c|}{ Posterior } \\
\hline & Mean & Mode & Mean & $5 \%, 95 \%$ \\
\hline AR(1) parameter, U.K. technology & 0.8500 & 0.9485 & 0.9302 & $\begin{array}{c}0.8788 \\
0.9797\end{array}$ \\
\hline $\begin{array}{c}\text { AR(1) parameter, U.K. wage Phillips } \\
\text { curve shocks }\end{array}$ & 0.8500 & 0.9218 & 0.8523 & $\begin{array}{l}0.7185 \\
0.9952\end{array}$ \\
\hline $\begin{array}{l}\text { AR(1) parameter, U.K. monetary policy } \\
\text { shocks }\end{array}$ & 0.8500 & 0.4752 & 0.4795 & $\begin{array}{l}0.3648 \\
0.5992 \\
\end{array}$ \\
\hline AR(1) parameter, U.K. IS shocks & 0.8500 & 0.9802 & 0.9760 & $\begin{array}{l}0.9594 \\
0.9984\end{array}$ \\
\hline $\begin{array}{c}\text { AR(1) parameter, U.K. price Phillips } \\
\text { curve shocks }\end{array}$ & 0.8500 & 0.9924 & 0.9872 & $\begin{array}{l}0.9754 \\
0.9984\end{array}$ \\
\hline AR(1) parameter, UIP shocks & 0.8500 & 0.9391 & 0.9265 & $\begin{array}{l}0.8792 \\
0.9753\end{array}$ \\
\hline $\mathrm{AR}(1)$ parameter, euro area technology & 0.8500 & 0.8147 & 0.7694 & $\begin{array}{l}0.6271 \\
0.9049\end{array}$ \\
\hline $\begin{array}{l}\text { AR(1) parameter, euro area wage } \\
\text { Phillips curve shocks }\end{array}$ & 0.8500 & 0.9218 & 0.8548 & $\begin{array}{l}0.7248 \\
0.9956\end{array}$ \\
\hline $\begin{array}{l}\text { AR(1) parameter, euro area monetary } \\
\text { policy shocks }\end{array}$ & 0.8500 & 0.2482 & 0.2563 & $\begin{array}{l}0.1773 \\
0.3356\end{array}$ \\
\hline AR(1) parameter, euro area IS shocks & 0.8500 & 0.9471 & 0.9388 & $\begin{array}{l}0.9120 \\
0.9643\end{array}$ \\
\hline $\begin{array}{l}\text { AR(1) parameter, euro area price } \\
\text { Phillips curve shocks }\end{array}$ & 0.8500 & 0.9882 & 0.9789 & $\begin{array}{l}0.9608, \\
0.9983\end{array}$ \\
\hline
\end{tabular}




\begin{tabular}{|c|c|c|c|c|}
\hline \multicolumn{5}{|c|}{$\begin{array}{c}\text { Table 1C. Bayesian estimates of EGL (2007) model on U.K. and euro area data } \\
\text { Estimation period 1981 Q1-2005 Q4 } \\
\text { Innovation variance/covariance estimates }\end{array}$} \\
\hline & Prior & Mode & Mean & $5 \%, 95 \%$ \\
\hline \multicolumn{5}{|c|}{ Standard deviation of innovations: } \\
\hline Technology, U.K. & $0.100 \%$ & $1.049 \%$ & $1.126 \%$ & $\begin{array}{c}0.899 \% \\
1.361 \%\end{array}$ \\
\hline Technology, euro area & $0.100 \%$ & $0.620 \%$ & $0.714 \%$ & $\begin{array}{c}0.528 \% \\
0.912 \%\end{array}$ \\
\hline Government spending, U.K. & $0.100 \%$ & $0.760 \%$ & $0.775 \%$ & $\begin{array}{c}0.673 \% \\
0.879 \%\end{array}$ \\
\hline Government spending, euro area & $0.100 \%$ & $0.610 \%$ & $0.620 \%$ & $\begin{array}{c}0.518 \% \\
0.718 \%\end{array}$ \\
\hline Monetary policy rule, U.K. & $0.100 \%$ & $0.213 \%$ & $0.217 \%$ & $\begin{array}{c}0.190 \% \\
0.244 \%\end{array}$ \\
\hline Monetary policy rule, euro area & $0.100 \%$ & $0.148 \%$ & $0.149 \%$ & $\begin{array}{l}0.129 \% \\
0.170 \%\end{array}$ \\
\hline UIP disturbance & $0.100 \%$ & $0.165 \%$ & $0.189 \%$ & $\begin{array}{c}0.129 \% \\
0.248 \%\end{array}$ \\
\hline Price Phillips curve shocks, U.K. & $0.100 \%$ & $1.045 \%$ & $1.049 \%$ & $\begin{array}{l}0.728 \% \\
1.346 \%\end{array}$ \\
\hline Price Phillips curve shocks, euro area & $0.100 \%$ & $0.915 \%$ & $0.898 \%$ & $\begin{array}{c}0.626 \% \\
1.140 \%\end{array}$ \\
\hline Wage Phillips curve shocks, U.K. & $0.100 \%$ & $0.046 \%$ & $0.078 \%$ & $\begin{array}{l}0.024 \% \\
0.149 \%\end{array}$ \\
\hline Wage Phillips curve shocks, euro area & $0.100 \%$ & $0.046 \%$ & $0.117 \%$ & $\begin{array}{l}0.022 \% \text {. } \\
0.241 \%\end{array}$ \\
\hline \multicolumn{5}{|c|}{ Note: Inverse gamma distribution prior used for estimation of standard deviations. } \\
\hline \multicolumn{5}{|c|}{ Cross-economy correlations of innovations } \\
\hline Technology & 0.000 & 0.159 & 0.149 & $\begin{array}{c}-0.018 \\
0.311\end{array}$ \\
\hline Government spending & 0.000 & 0.233 & 0.226 & $\begin{array}{l}0.050 \\
0.406\end{array}$ \\
\hline
\end{tabular}


With the partial exception of the monetary policy shocks, which have only moderate autocorrelation, all the estimated shocks in the model are strongly persistent. In particular, the UIP shock is highly serially correlated. This autocorrelation combines with the estimated innovation variance to give an unconditional standard deviation for the UIP shock of about $0.5 \%$, a surprisingly modest value.

There is considerable asymmetry in the real shocks facing each economy, with the correlation between innovations to technology being below 0.2 and that between government spending innovations being below 0.3 . This is consistent with previous evidence for European economies. For example, Söderström (2008, p. 10) argues that "asymmetric shocks seem to be important for the Swedish economy," while Artis and Ehrmann's (2006) VAR analysis suggests that German and U.K. real shocks may even be negatively correlated.

A serious question raised about empirical open-economy DSGE models is raised by Justiniano and Preston (2006). They argue that estimated (small) open-economy structural models understate the contribution of international shocks to an open economy's economic fluctuations. In their empirical example of the United States and Canada, the U.S. shocks in combination contribute about two-thirds to Canadian output fluctuations in an identified VAR, but to less than $10 \%$ of Canadian output variation in the estimated DSGE model. We have looked at the impact on our results of this problem by comparing our estimated open-economy structural model for the euro area and the United Kingdom with an identified VAR including data for the two economies. The VAR is a four-lag system consisting of a major subset of the variables we use in estimation of the structural model: namely, output growth, inflation, and interest rates for both economies, as well as the change in the nominal exchange rate. The VAR identified shocks are obtained with a Choleski decomposition, with euro variables ordered first, followed by the exchange rate, then the U.K. variables, and the ordering of the variables within each block being: interest rate; output growth; inflation. This identified VAR delivers an estimated contribution of foreign shocks (including the exchange rate shock) to U.K. output growth variability of $32.7 \%$. The contribution of foreign shocks (including the UIP shock) to U.K. output growth variation in the estimated structural model, on the other hand, is $29.9 \%$. The results differ from Justiniano and Preston's in two respects. First, for the identified VAR, the estimated foreign contribution to domestic economic variability is more modest in our example - and this is despite the fact that we do, and Justiniano and Preston do not, include the exchange rate shock among the foreign shocks. 
Second, in moving to the structural model, we do not find a dramatically smaller contribution of foreign shocks' contribution to domestic economic fluctuations. In that sense, the understatement problem for our euro area/U.K. structural model is less serious than that found by Justiano and Preston (2006) for their open-economy model of the United States and Canada. But this finding is subject to the proviso that, as noted above, we categorize exchange-rate shocks in both the VAR and structural models as foreign shocks. It is true that most of the foreign contribution to U.K. output variation in our structural model comes from this source, whereas in the VAR, the shocks to the euro-area variables form the bulk of the foreign influence on U.K. output growth.

\section{Simulation experiments}

In this section we present illustrative results from simulations of the model. We consider three assumptions about model structure, starting with the estimated model as the baseline.

\section{A. Baseline case}

In the baseline case in Table 2, we assess U.K. economic performance using the estimated model under different monetary policy rules: historical policy and monetary union. We focus on variability of output, CPI inflation, and the short-term nominal interest rate. We acknowledge that open-economy models like those used in this paper frequently do not justify a monetary policy focus on aggregate CPI inflation, and direct attention instead to domestic-goods inflation or to a combination of domestic-goods and wage inflation. But CPI inflation is bound to be a key variable in a study of U.K. policy options. That is the inflation rate focused upon in the U.K. current policy framework, and so is a key variable to consider in judging the merits of U.K. entry into monetary union.

Historical policy uses the U.K. and euro area interest-rate rules set out in the estimated model. The mode values in Tables $1 \mathrm{~A}$ to $1 \mathrm{C}$ are taken to be the model estimates. When we consider monetary union, the historical U.K. policy rule is dropped in favor of $R_{t}^{U . K .}=$ $R_{t}^{E A}$ (where "EA" denotes euro area), and since the United Kingdom is then a euro area member, the euro area output and price aggregates that enter the euro area policy rule include the corresponding U.K. series. The price aggregate is assumed to be a loglinear combination of the non-U.K. and U.K. economies' output deflators. Subject to these 
Table 2. Simulation results

\begin{tabular}{|l|c|c|c|}
\hline & \multicolumn{3}{|c|}{ Standard deviation (percent) of United Kingdom: } \\
\hline & $\begin{array}{c}\text { CPI inflation } \\
\text { (annualized) }\end{array}$ & Output gap & $\begin{array}{c}\text { Nominal interest rate } \\
\text { (annualized) }\end{array}$ \\
\hline
\end{tabular}

A. Baseline model (Common structure to both economies)

\begin{tabular}{|l|c|c|c|}
\hline Historical rules & 4.76 & 3.33 & 5.11 \\
\hline $\begin{array}{l}\text { Monetary union } \\
\text { (UIP shocks continue) }\end{array}$ & 4.02 & 3.19 & 2.67 \\
\hline $\begin{array}{l}\text { Monetary union } \\
\text { (UIP shocks vanish) }\end{array}$ & 3.87 & 3.19 & 2.57 \\
\hline
\end{tabular}

B. Model with greater wage flexibility in United Kingdom

\begin{tabular}{|l|c|c|r|}
\hline Historical rules & 4.78 & 3.34 & 5.12 \\
\hline $\begin{array}{l}\text { Monetary union } \\
\text { (UIP shocks continue) }\end{array}$ & 17.66 & 4.82 & 2.58 \\
\hline $\begin{array}{l}\text { Monetary union } \\
\text { (UIP shocks vanish) }\end{array}$ & 17.53 & 4.81 & 2.49 \\
\hline
\end{tabular}

C. Model with U.K. imports predominantly intermediates

\begin{tabular}{|l|c|c|c|}
\hline Historical rules & 4.71 & 2.72 & 5.32 \\
\hline $\begin{array}{l}\text { Monetary union } \\
\text { (UIP shocks continue) }\end{array}$ & 5.05 & 2.64 & 2.72 \\
\hline $\begin{array}{l}\text { Monetary union } \\
\text { (UIP shocks vanish) }\end{array}$ & 4.96 & 2.64 & 2.62 \\
\hline
\end{tabular}


augmented definitions of the aggregates, the interest-rate policy rule assumed for the monetary union is the same as that estimated empirically for the euro area: smoothing of 0.79 , a response to lagged quarterly inflation that implies a 1.27 "long-run" response, and a response to lagged detrended output that implies a 0.085 "long-run" reaction. ${ }^{19}$

Historical policy in our parameterized model gives, as reported in Table 2, standard deviations of $4.8 \%$ for inflation, $3.3 \%$ for the output gap, and 5.1\% for the nominal interest rate. The alternative regime of monetary union is considered with and without UIP shocks. When UIP shocks are present, they act in a way that does not disturb equality of interest rates across economies; instead, UIP shocks effectively become a second IS shock and so a source of disturbance to output demand. According to Table 2, monetary union reduces output gap variability and does so irrespective of the assumption about the presence of UIP shocks. Improvement in U.K. inflation stabilization does occur with monetary union but is somewhat dependent on whether union eliminates UIP shocks. The standard deviation of U.K. inflation falls if UIP shocks vanish. Nevertheless, even when UIP shocks are present, their effect on the results is not dramatic, apparently because our estimates imply a fairly modest variance for this class of shock.

\section{B. Wages relatively more flexible in the United Kingdom}

Estimates of a dynamic general equilibrium model for the United Kingdom in DiCecio and Nelson (2007) suggested that U.K. nominal rigidity was concentrated in prices, rather than spread across wages and prices equally. This finding is roughly reflected in our estimates here too. But it is puzzling that we also find that the probability of wage adjustment is also quite rapid in the euro area, which contrasts with estimates such as those of Smets and Wouters (2003). In light of this, we now consider an alternative parameterization of the EGL model in which wages are more flexible in the United Kingdom than in the euro area. Specifically, we raise the degree of nominal rigidity in the euro area above its estimated value. It is now assumed that the probability that wages are not reoptimized is 0.60 in the euro area.

\footnotetext{
${ }^{19}$ The monetary policy shock autocorrelation and variances for the policymaker in the monetary union, are also those estimated in Tables $1 \mathrm{~B}$ and $1 \mathrm{C}$ for the euro area.
} 
We report the simulation outcomes in the middle set of results (Case B) in Table 2. When there is no monetary union, the standard deviations of U.K. series are virtually unchanged from those under the baseline parameterization. Since the only change in parameterization is to the degree of euro area wage rigidity, the results make economic sense; they reflect the notion that floating exchange rates can insulate the domestic economy from divergences across economies in the degree of nominal rigidity. The loss of the exchange rate mechanism and of an own-economy interest-rate rule now seem to have visible costs; U.K. inflation stabilization worsens drastically under monetary union, when compared to that under the historical U.K. monetary policy rule, regardless of whether UIP shocks are present. The magnitude of the difference in inflation variability implied by historical rules and that implied by monetary union is very large in Table 2 , and may be questioned. The difference would likely be more modest if, for example, we had assumed a more modest divergence between U.K. and euro area nominal rigidity. ${ }^{20}$ We would not give credence to the quantitative magnitude of the results from this model setting. But, qualitatively, the results illustrate the possibility that nominal exchange rate movements help compensate for differences in nominal rigidities across countries.

As in the previous set of results, U.K. interest-rate variability does decline when there is monetary union. Thus embrace of monetary union appears to confer on the United Kingdom more stable interest rates, but these are accompanied by a rule that is directed at aggregates of which U.K. variables make up only a modest portion. Furthermore, the mismatch of contract durations across economies means that rules that are successful at stabilizing euro area inflation are less effective at stabilizing U.K. fluctuations. The net outcome is greater U.K. macroeconomic instability.

Monetary policy is less volatile in the sense that interest rate volatility declines when the United Kingdom joins the union; it gives up a domestic policy rule that was associated with less smooth interest rate behavior. But inflation outcomes become more volatile for the U.K. economy. What appears to be happening is that the less volatile rate behavior is destabilizing for U.K. inflation because of the major mismatch in nominal rigidity; i.e., the interest rate should be more volatile, or should be responding in a different way to shocks than what is implied by the euro rule, if the objective is to insulate the U.K.

\footnotetext{
${ }^{20}$ Equally, we found that making the discrepancy in nominal rigidity across the two economies larger than that used in Figure 2 worsens the variability of U.K. inflation.
} 
economy from the effects of nominal rigidity. ${ }^{21}$ The damage done by the imposition of the euro area rule overwhelms one beneficial effect on inflation variability arising from euro area wage patterns. This beneficial effect is that the relatively greater euro area wage stickiness by itself should be helpful for U.K. inflation stabilization by stabilizing U.K. import price inflation. This partial effect seems to dominate when the difference in wage stickiness across economies is a little less than what we are using in the table.

\section{Intermediate goods predominant}

We revert our settings of wage rigidity to the estimates in Table 1 in order to consider a third model variant. Wilson (1976) and Allsopp, Kara, and Nelson (2006) argue that, for U.K. inflation analysis, it is appropriate to model all imports as intermediate goods. With this formulation, imports enter the model alongside labor in the production process to yield final consumption goods. We consider a parameterization of the EGL model that allows for this view of imports' role to predominate. In the baseline parameterization, $100 \%$ of imports were final consumer goods; now, by contrast, $90 \%$ of imports are assumed to be intermediate goods and only $10 \%$ to be final goods. ${ }^{22}$ We repeat the policy experiments with this alternative setting of the model in the final segment of Table 2. Monetary union appears to worsen inflation performance somewhat-even when UIP shocks are absent - and to reduce the variability of the output gap and the interest rate. When imports are primarily intermediates, exchange rate variations have a less automatic connection to CPI variations; the fraction of the CPI that is flexible and linked tightly to the exchange rate is small. Under these conditions, extinguishing exchange rate variations is less likely to deliver improved inflation performance, if this also entails giving up the ability to manipulate domestic interest rates.

\footnotetext{
${ }^{21}$ Output gap variability falls under union. In a closed-economy sticky-price model with no Phillips curve shocks and no indexation, this reduction would by itself imply that policymakers had succeeded in removing the effects of nominal rigidity; it would necessarily be associated also with lower inflation variability. But this implication does not carry over to the present model. Because there are several sources of nominal rigidity in the open-economy model we use, as well as Phillips curve shocks, the stability of the U.K. output gap is not a reliable index (as it is in a sticky-price closed-economy model) of the effects of nominal rigidity, so CPI inflation is destabilized by the euro rule despite the accompanying improved stability of the gap.

${ }^{22}$ The intermediate technology is that in EGL (2007), including a 1/3 weight on imports.
} 


\section{Conclusions}

We have considered euro area membership as a U.K. monetary policy option by studying the effect of monetary union under various parameterizations of the Erceg, Gust, and López-Salido (2007) model. One issue in determining whether monetary union contributes to an improvement in U.K. macroeconomic stabilization is the status of the "UIP," or foreign exchange risk-premium, shock. Much hangs on whether the elimination of the sterling/euro exchange market will be associated with the suppression of UIP shocks, which have been thought to be a major source of exchange rate variation. Suppose these shocks stand in for pressures that the economy needs to adjust to whether it is part of a monetary union or not. Then if the United Kingdom joined the euro area, UIP shocks, instead of vanishing, would continue to make themselves felt via different channels. Our results suggest that monetary union may increase inflation variability if UIP shocks do not disappear at the inception of monetary union. This effect is detectable even though, according to our estimates, UIP shocks are actually only a modest inherent source of exchange rate variation.

We also affirmed that if the differences in the degree of nominal wage rigidity across the United Kingdom and the euro area are sufficiently large, U.K. inflation variability under monetary union is higher than that achievable under monetary policy autonomy. Finally, we found that the improvement in U.K. economic stability under monetary union also diminishes if imports from the euro area are modeled as primarily intermediates instead of finished goods. 


\section{Appendix. The Erceg, Gust, and López-Salido (EGL) model setup}

The EGL (2007) setup, as applied here, consists of 25 equations determining the following 25 endogenous variables (with real variables in log-deviation form):

$$
\left\lfloor c_{t}{ }^{j}, y_{t}{ }^{j}, l_{t}{ }^{j}, c_{D, t}{ }^{j}, m_{C, t}{ }^{j}, \pi_{t}{ }^{j}, \pi_{C, t}{ }^{j}, \pi_{w, t}{ }^{j}, p_{C D, t}{ }^{j}, \zeta_{t}{ }^{j}, R_{t}{ }^{j}, \rho_{t}, \tau_{t}, s_{t}\right\rfloor j=U . K ., E A,
$$

where EA denotes "euro area."

The consumption bundles in each economy consist of the aggregates:

$$
c_{t}^{j}=\left(1-\omega^{j}\right) c_{D, t}^{j}+\omega^{j} m_{C, t}{ }^{j}, j=U . K ., E A,
$$

where $c$ is total consumption, $c_{D}$ is consumption of domestically produced output, and $m_{C}$ denotes imported consumption goods. The two-economy structure implies that $\omega^{\text {U.K. }}=$ $v \omega^{E A}$.

Production functions take the form:

$$
y_{t}^{j}=z_{t}^{j}+l_{t}^{j}, j=U . K ., E A,
$$

so that output (expressed as a log-deviation from its steady state value) is equal to the sum of the technology shock, $z$, and log labor input, $l$.

The resource constraints imply:

$$
y_{t}^{j}=c_{t}^{j}, j=U . K ., E A .
$$

There is a risk-sharing condition:

$$
\sigma\left(c_{t}^{U K}-\frac{g_{C}^{U K}}{1-g_{C}^{U K}} g_{t}^{U K}\right)=\rho_{t}+\sigma\left(c_{t}^{E A}-\frac{g_{C}^{E A}}{1-g_{C}^{E A}} g_{t}^{E A}\right)
$$

where $\rho_{t}$ is the real exchange rate, and the $g$ 's are IS shocks. 
The intertemporal Euler equation for household consumption in the euro area is

$$
\sigma\left(C_{t}^{E A}-\frac{g_{C}^{E A}}{1-g_{C}{ }^{E A}} g_{t}^{E A}\right)=\sigma\left(\mathrm{E}_{t} C_{t+1}^{E A}-\frac{g_{C}^{E A}}{1-g_{C}^{E A}} \mathrm{E}_{t} g_{t+1}^{E A}\right)-\left(R_{t}^{E A}-\mathrm{E}_{t} \pi_{C, t+1}{ }^{E A}\right)
$$

where $\left(R-\pi_{C}\right)$ is the euro area short-term real interest rate (measured in consumption units).

The demand functions for imported consumer goods are given by:

$$
\begin{aligned}
& m_{C, t}{ }^{U K}=c_{D, t}{ }^{U K}-\eta \tau_{t}, \\
& m_{C, t}{ }^{E A}=c_{D, t}{ }^{E A}+\eta \tau_{t} .
\end{aligned}
$$

Wages are governed by the relations:

$$
\begin{aligned}
& \frac{\xi_{w}{ }^{j}\left(1+\chi \frac{1+\theta_{w}}{\theta_{w}}\right)}{\left(1-\xi_{w}{ }^{j}\right)\left(1-\beta \xi_{w}{ }^{j}\right)}\left[\pi_{w, t}{ }^{j}-\pi_{w, t-1}^{j}-\beta\left(\mathrm{E}_{t} \pi_{w, t+1}{ }^{j}-\pi_{w, t}{ }^{j}\right)\right]={ }_{j=U . K .,} E A, \\
& =\left[\chi l_{t}^{j}+\sigma\left(c_{t}^{j}-\frac{g_{C}{ }^{j}}{1-g_{C}{ }^{j}} g_{t}^{j}\right)+\mu_{w, t}{ }^{j}-\left(\zeta_{t}{ }^{j}-p_{C D, t}{ }^{j}\right)\right] \text {, }
\end{aligned}
$$

where $\pi_{w}$ is nominal wage inflation, $\left(\zeta-p_{C D}\right)$ is the log real wage in consumption units (i.e., the $\log$ real wage in output units, $\zeta$, adjusted for the log aggregate relative price of consumer goods in terms of output, $\left.p_{C D}\right) ; \mu_{w}$ is a wage markup shock. The parameters $\theta_{w}$ (common across economies) and $\xi_{w}$ (different across economies) respectively denote the steady-state wage markup and an index of the degree to which households are not given clearance to reoptimize nominal wages.

Price inflation is driven by the Phillips curve:

$$
\pi_{t}^{j}-\pi_{t-1}^{j}-\beta\left(\mathrm{E}_{t} \pi_{t+1}^{j}-\pi_{t}^{j}\right)=\frac{\left(1-\xi_{p}^{j}\right)\left(1-\beta \xi_{p}^{j}\right)}{\xi_{p}^{j}}\left(\zeta_{t}^{j}-z_{t}^{j}\right)+\mu_{p, t}^{j}, j=\text { U.K., EA, }
$$


where $\pi$ is the GDP deflator inflation rate; the probability $\xi_{p}$ indexes the degree of nominal price stickiness; and $\mu_{p}$ is a price markup shock.

The percent change in the real wage (in output units) is simply the difference between wage and price inflation,

$$
\zeta_{t}^{j}-\zeta_{t-1}^{j}=\pi_{w, t}^{j}-\pi_{t}^{j}, j=U . K ., E A .
$$

The prices of consumption relative to output are connected to the terms of trade as follows:

$$
\begin{aligned}
& p_{C D, t}^{U K}=\omega^{U K} \tau_{t}, \\
& p_{C D, t}^{E A}=-\omega^{E A} \tau_{t} .
\end{aligned}
$$

The growth rate of consumer prices (relative to output prices) can be written as the spread between consumer price and output price inflation:

$$
p_{C D, t}^{j}-p_{C D, t-1}^{j}=\pi_{C, t}{ }^{j}-\pi_{t}^{j}, j=U . K ., E A .
$$

The real exchange rate has the following relation to the terms of trade:

$$
\rho_{t}=\left(1-\omega^{U K}-\omega^{E A}\right) \tau_{t}
$$

The following uncovered interest rate parity condition (in real terms) holds:

$$
\mathrm{E}_{t} \tau_{t+1}-\tau_{t}=\left(R_{t}^{U K}-\mathrm{E}_{t} \pi_{t+1}^{U K}\right)-\left(R_{t}^{E A}-\mathrm{E}_{t} \pi_{t+1}{ }^{E A}\right)+\text { euip }_{t}
$$

where euip is the UIP shock.

The percent change in the nominal exchange rate can be expressed as:

$$
S_{t}-S_{t-1}=\tau_{t}-\tau_{t-1}+\pi_{t}^{U K}-\pi_{t}^{E A} .
$$

In the case of no monetary union, we assume the monetary policy rules take the form: 


$$
\begin{aligned}
& R_{t}^{U . K .}=\rho_{R}^{U . K .} R_{t-1}^{U . K .}+\left(1-\rho_{R}^{U . K .}\right)\left(\frac{\gamma_{\pi}^{U . K .}}{4} \sum_{j=1}^{4} \pi_{C, t-j}^{U . K .}+\gamma_{y}^{U . K .} y_{t-1}^{U . K .}\right)+e_{R t}^{U . K .}, \\
& R_{t}^{E A}=\rho_{R}{ }^{E A} R_{t-1}{ }^{E A}+\left(1-\rho_{R}{ }^{E A}\right)\left(\gamma_{\pi}{ }^{E A} \pi_{t-1}{ }^{E A}+\gamma_{y}{ }^{E A} y_{t-1}{ }^{E A}\right)+e_{R t}{ }^{E A},
\end{aligned}
$$

the $e_{R t}$ being $\mathrm{AR}(1)$ monetary policy shocks.

The eleven exogenous stochastic processes $\left[z^{j}, g^{j}, \mu_{w}{ }^{j}, \mu_{p}{ }^{j}, e_{R}{ }^{j}\right.$, euip $]$ are each assumed to be follow AR(1) laws of motion.

The preceding outline features imports only as final consumer goods. EGL (2007) also present a version of their model with some imports being intermediates. We use a version of this model, making the assumption that some imports into the U.K. economy are used for production, in our Case $\mathrm{C}$ experiments in Table 2. 


\section{References}

Allsopp, Christopher, Amit Kara, and Edward Nelson (2006). "United Kingdom Inflation Targeting and the Exchange Rate,” Economic Journal 116, F232-F244.

Artis, Michael, and Michael Ehrmann (2006). "The Exchange Rate-A Shock-Absorber or Source of Shocks? A Study of Four Open Economies," Journal of International Money and Finance 25, 874-893.

Associated Press (1972). “Briton Predicts European Nuclear Buildup,” Baltimore Sun, October 14, p. A5.

Bank of England (1999). The Transmission Mechanism of Monetary Policy. London: Bank of England.

Benati, Luca (2008). "The Great Moderation in the United Kingdom," Journal of Money, Credit and Banking 40, 121-147.

Blanchard, Olivier (1997). Macroeconomics. Upper Saddle River, N.J.: Prentice Hall.

Boero, Gianna, Jeremy Smith, and Kenneth F. Wallis (2008). "Modelling U.K. Inflation Uncertainty 1958-2006." Manuscript, University of Warwick.

Buiter, Willem H. (1999). "Optimal Currency Areas: When Does the Exchange Rate Regime Matter? With an Application to U.K. Membership in Euro.” November. (http://www.nber.org/\%7Ewbuiter/scotland.pdf).

Castle, Barbara (1980). The Castle Diaries 1974-1976. London: Weidenfeld and Nicolson.

Cobham, David (2006). “The Overvaluation of Sterling Since 1996: How the Policy Makers Responded and Why," Economic Journal 116, F185-F207.

Commission of the European Communities, Working Party on Economic and Monetary Union (1970). Interim Report on the Establishment by Stages of Economic and Monetary Union in the Community. Brussels: European Communities. 
Corsetti, Giancarlo, Luca Dedola, and Sylvain Leduc (2007). "Optimal Monetary Policy and the Sources of Local-Currency Price Stability.” NBER Working Paper No. 13544.

DiCecio, Riccardo, and Edward Nelson (2007). "An Estimated DSGE Model for the United Kingdom," Federal Reserve Bank of St. Louis Review 89, 215-231.

Erceg, Christopher (2002). "The Choice of an Inflation Target Range in a Small Open Economy," American Economic Review (Papers and Proceedings) 92, 85-89.

Erceg, Christopher, Christopher Gust, and J. David López-Salido (2007). “The Transmission of Domestic Shocks in the Open Economy.” NBER Working Paper No. 13613 and Federal Reserve Board International Finance Discussion Paper No. 906.

Expenditure Committee, House of Commons (1978). First Report from the Expenditure Committee: The European Monetary System. November 20. London: HMSO.

Fagan, Gabriel, Jerome Henry, and Ricardo Mestre (2001). “An Area Wide Model (AWM) for the Euro Area.” ECB Working Paper No 42.

Faia, Ester, and Tommaso Monacelli (2008). "Optimal Monetary Policy in a Small Open Economy with Home Bias,” Journal of Money, Credit and Banking 40, 721-750.

Favero, Carlo A. (2001). Applied Macroeconometrics. Oxford, U.K.: Oxford University Press.

Friedman, Milton (1983). "The Keynes Centenary: A Monetarist Reflects," The Economist, June 4, 35-37.

HM Treasury (2003a). U.K. Membership of the Single Currency-An Assessment of the Five Economic Tests: Executive Summary. www.hm-treasury.gov.uk.

HM Treasury (2003b). U.K. Membership of the Single Currency-An Assessment of the Five Economic Tests: Chapter 1: Convergence. www.hm-treasury.gov.uk. 
Justiniano, Alejandro, and Bruce Preston (2006). "Can Structural Small Open Economy Models Account for the Influence of Foreign Disturbances?" Manuscript, Columbia University.

Kahn, Richard F. (1956). "Lord Keynes and the Balance of Payments," The Listener, May 10, 591-593. Reprinted in R.F. Kahn, Selected Essays on Employment and Growth. Cambridge, U.K.: Cambridge University Press, 1972. 113-123.

MacRae, Penny (1999). "Poll-U.K. Given 65 Per Cent Chance of Joining Euro." Reuters News, June 7.

McCallum, Bennett T., and Edward Nelson (1999). "Nominal Income Targeting in an Open-Economy Optimizing Model,” Journal of Monetary Economics 43, 553-578.

Minford, Patrick (2002). Should Britain Join the Euro? The Chancellor's Five Tests Examined. London: Institute of Economic Affairs.

Monacelli, Tommaso (2005). "Monetary Policy in a Low Pass-Through Environment," Journal of Money, Credit and Banking, 37, 1047-1066.

Nelson, Edward (2008). "An Overhaul of Doctrine: The Underpinning of U.K. Inflation Targeting.” Working Paper, Federal Reserve Bank of St. Louis, August; Economic Journal, forthcoming.

Rotemberg, Julio J., and Michael Woodford (1997). "An Optimization-Based Econometric Framework for the Evaluation of Monetary Policy," NBER Macroeconomics Annual 12, $297-346$.

Rubio, Margarita (2008). "Fixed and Variable-Rate Mortgages, Business Cycles and Monetary Policy.” Manuscript, Boston College.

Smets, Frank, and Rafael Wouters (2002). “Openness, Imperfect Exchange Rate PassThrough and Monetary Policy," Journal of Monetary Economics 49, 947-981. 
Smets, Frank, and Rafael Wouters (2003). "Monetary Policy in an Estimated SDGE Model of the Euro Area", Journal of the European Economic Association 1, 1123-1175.

Smets, Frank, and Rafael Wouters (2005). "Comparing Shocks and Frictions in U.S. and Euro Area Business Cycles: A Bayesian DSGE Approach,” Journal of Applied Econometrics 20, 161-183.

Smets, Frank, and Rafael Wouters (2007). "Shocks and Frictions in U.S. Business Cycles: A Bayesian DSGE Approach,” American Economic Review 97, 586-606.

Söderström, Ulf (2008). "Re-Evaluating Swedish Membership in the EMU: Evidence from an Estimated Model.” Manuscript, Sveriges Riksbank.

Stephens, Philip (1997). Politics and the Pound: The Tories, the Economy and Europe. London: Papermac.

Stock, James H., and Mark Watson (2002). "Has the Business Cycle Changed and Why?," NBER Macroeconomics Annual 17, 159-218.

Study Group on the Role of Public Finance (1977). Report of the Study Group on the Role of Public Finance in European Integration, Volume 1: General Report. Economic and Financial Series, Commission of the European Economic Communities.

Surico, Paolo (2008). "Monetary Policy Shifts and Inflation Dynamics." Bank of England Working Paper No. 338.

Wilson, Thomas (1976). "Effective Devaluation and Inflation," Oxford Economic Papers 28, 1-24.

Woodford, Michael (2001). "Monetary Policy in the Information Economy." In Federal Reserve Bank of Kansas City, Economic Policy for the Information Economy. Kansas City, MO: Reserve Bank of Kansas City. 297-370.

Woodford, Michael (2007). "Globalization and Monetary Control.” NBER Working Paper No. 13329. 